\title{
CFD Analysis into the Correlation between Resistance and Seakeeping of Trimaran Configuration
}

\author{
Richard Benny Luhulima ${ }^{1, a, *}$, I Ketut Aria Pria Utama ${ }^{2, b}$, Sutiyo $^{3, c}$ and Bagiyo Suwasono $^{3, d}$ \\ ${ }^{1}$ Department of Naval Architecture, University of Patimurra, Ambon, Indonesia \\ ${ }^{2}$ Department of Naval Architecture, Institut Teknologi Sepuluh Nopember, Surabaya, Indonesia \\ ${ }^{3}$ Department of Naval Architecture, University of Hang Tuah, Surabaya, Indonesia \\ a.richard.b.l@fatek.unpatti.ac.id,b.kutama@na.its.ac.id,c.utiyo@hangtuah.ac.id, \\ d.bagiyo.suwasono@hangtuah.ac.id \\ *corresponding author
}

Keywords: $\quad$ CFD, Trimaran, Resistance, Seakeeping, Correlation.

\begin{abstract}
The development of marine transportation is growing rapidly to fulfil human needs. Furthermore, the use of trimaran vessels desperately needs to be developed to transport human and goods. The use of trimaran is very advantageous because it has large deck area compared to monohull with similar displacement. The calculation of trimaran vessel resistance with variations in the distance of the main hull and side hull transversely using Computational Fluid Dynamic approach was carried out. Then, seakeeping analysis is done to obtain the ship motion. Both resistance and seakeeping calculations were analyzed for resistance and seakeeping correlation. The results of numerical studies indicate that there is unique interference resistance in trimaran hull to transverse distance between hulls. The smaller distance between trimaran hulls, the greater resistance caused by interference of the constraints components that occur. Then, the apparent correlation between resistance and seakeeping is the increasing interference that causes heave and pitch motion to decrease. Interference does not affect roll motion. The numerical analysis shows that at a distance between hulls transversely 0.4 shows excellent results for performance of resistance and seakeeping.
\end{abstract}

\section{Introduction}

At this time, the growth of sea transport demand is increasing. it is also supported by government programs with "Tol Laut" programs to realize the world's maritime axis. Indonesia is the largest archipelagic country in the world. Therefore, require very large ship to connect between islands

Trimaran vessels are very suitable to operate in Indonesia waters, covering closed waters (lakes and rivers), restricted waters (strait, inter-island adjacent), and open waters, e.g. Java Sea and Arafuru Sea. Application of restricted and open waters is in the Maluku Islands region. The Maluku Sea has two different waters zones characteristic, namely the restricted waters that is still categorized by the calm sea that has wave height below 1 meter and open seas waters with wave height can reach 3-5 
meters height [1]. High sea waves accompanied by extreme and rapidly changing weather conditions can cause discomfort and may further threaten the safety of the soul at sea.

With the distance between the various islands, where there is a close and some are very far away. Hence, to reach one island to another island can pass restricted waters and can also pass through the open waters. Figure 1 illustrates the condition of the Maluku archipelago. Figure 1.a illustrates closerange voyage and Figure 1.b shows distant voyage. The two different voyage ranges represent different wave conditions. At restricted waters has wave height $0-1 \mathrm{~m}$ and open waters has wave height over $1 \mathrm{~m}$ and that it can reach 3-4 $\mathrm{m}$ [2].

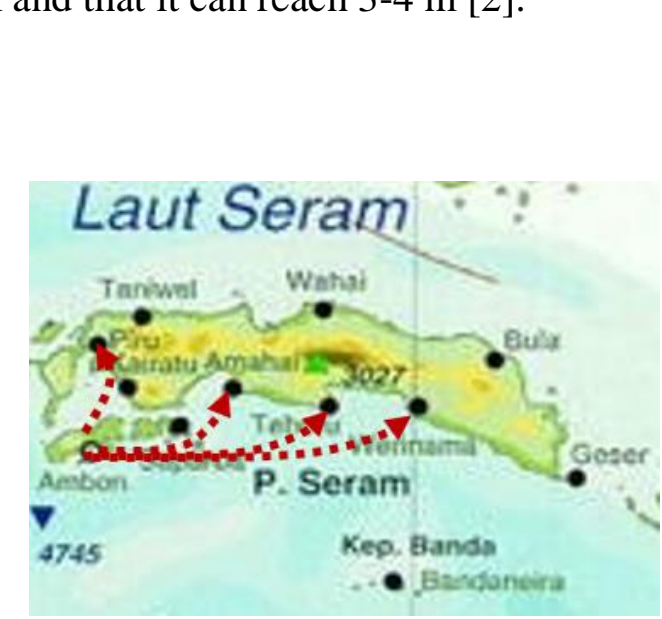

(a)

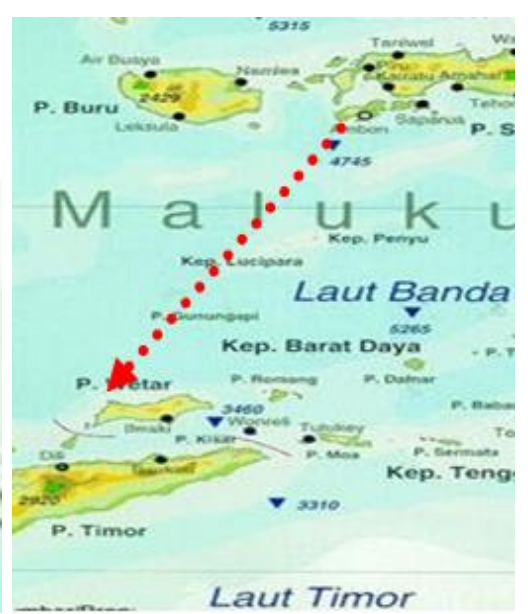

(b)

Figure 1. Maluku archipelago, (a). Close-range voyage. (b). Distant voyage

The large demand for ships to meet the needs of marine transportation in the Maluku Islands (Provincial Maluku and North Maluku). The demand availability of various ship types and shapes in sufficient quantities. The ships can be either a type of displacement or a semi-displacement (planning) vessel. According to records from the most of the vessels operating in the Maluku Waters have length (LBP) below 60 meters [3]. The ships, for the most part, cannot operate maximally in severe weather conditions (severe weather), especially in April to June and October to December, where wave heights reach 3-5 meters [1].

This paper is intended to explain the characteristics of variable trimaran vessel modes that operated in restricted waters such as the Maluku Waters. The aspects studied are the problems of resistance and seakeeping carried out through numerical models based on computational fluid dynamics (CFD).

\section{Ship Resistance}

Froude explains that the total ship resistance consists of friction resistance and residual resistance that are dominated by wave resistance. Froude emphasizes that the frictional resistance of a ship's shape is summation frictional resistance of a flat plate with wetted surface area [4]. Mathematically, the Froude formulation is expressed in terms of coefficients as:

$$
\mathrm{C}_{\mathrm{T}}=\mathrm{C}_{\mathrm{F}}+\mathrm{C}_{\mathrm{R}}
$$

Where, $C_{T}$ is the total resistance coefficient, $C_{F}$ is the coefficient of friction resistance, and $C_{R}$ is the remaining resistance coefficient.

Furthermore, Molland in 2008 classifies this constraint component into two groups: viscous resistance and wave resistance and is shown in Figure 2 [5]. 


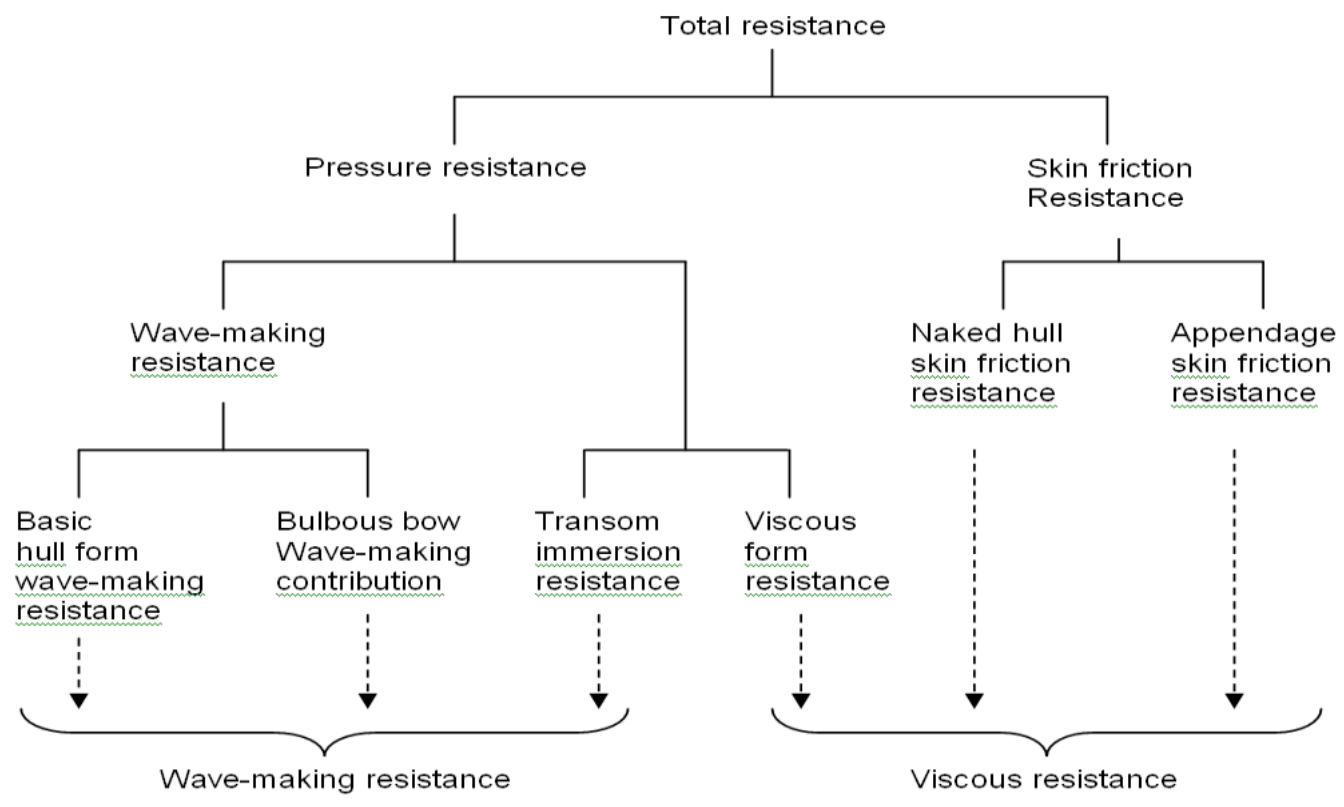

Figure 2. The Component Diagram of Ship Resistance.

The 2-dimensional analysis method is considered insufficient to explain the contribution of hull contours to the viscosity resistance, so that later Hughes introduced a method for use in model correlations to ships where the total resistance is sum from 3 (three) components: frictional resistance (skin friction), form resistance, and wave resistance $(\mathrm{CW})$. The wave resistance is the reduction of total resistance (CT) of the addition of frictional resistance (CF) and form resistance [6]. Mathematically, the statement is formulated (in coefficient form) as:

$$
\mathrm{C}_{\mathrm{T}}=(1+\mathrm{k}) \mathrm{C}_{\mathrm{F}}+\mathrm{CW}_{\mathrm{W}}
$$

Where $\mathrm{CW}_{\mathrm{W}}$ is the wave resistance coefficient, $(1+\mathrm{k})$ is the form factor and $(1+\mathrm{k}) \mathrm{C}_{\mathrm{F}}$ is the coefficient of viscosity resistance hereinafter expressed as $\mathrm{C}_{\mathrm{V}}$. The $\mathrm{C}_{\mathrm{F}}$ is calculated by the ITTC-1957 correlation line set in Madrid, Spain [7]:

$$
C_{F}=\frac{0.075}{(\log (R e)-2)^{2}}
$$

Trimaran ship resistance is assumed to be the sum of some independent components to easily solve the hull resistance problem and the effect of the distance between the hull clearance.

The interference effects between the hulls which modify the inhibitory components of the trimaran ship hull configuration may be described as modifications to ITTC-1957, ITTC-1978 [8] and direct measurement methods for calculating trimaran ship resistance.

The calculation of trimaran vessel resistance adopts a single hull resitance (monohull) method by including interference factors as follows:

$$
\begin{aligned}
\left(\mathrm{C}_{\mathrm{T}}\right)_{\text {Trim }} & =\left(\mathrm{C}_{\mathrm{F}}\right)_{\text {Trim }}+\left(\mathrm{C}_{\mathrm{R}}\right)_{\text {Trim }} \\
& =\sigma \mathrm{C}_{\mathrm{F}}+\Omega \mathrm{C}_{\mathrm{R}}
\end{aligned}
$$

Where $\sigma$ is interference factor of friction resistance (friction) and $\Omega$ is interference factor of residual restriction (residuary). 
Insel and Molland [9] reveal the characteristics of high-speed semi displacement catamaran in calm water with symmetrical hull forms. The results experiments concluded that the influence of both interferences contributes to total ship resistance are viscous interference is flow around the demihull and wave interference due to the wave interaction of each of its hulls.

The Trimaran will be analysed on the Froude Number $0.15-0.27$ number for the trimaran configuration with the distance ratio $(\mathrm{S} / \mathrm{L}) 0.2 ; 0.3 ; 0.4$ and 0.5 . The Total resistance for hull is $\mathrm{RT}$ however it has be divided into the two equal resistances are $\mathrm{R}_{\mathrm{TSideh}}$ and $\mathrm{R}_{\mathrm{TM}} \mathrm{ainhull}$.

$$
\mathrm{R}_{\mathrm{T}}=2 \mathrm{R}_{\mathrm{TSidehull}}+\mathrm{R}_{\mathrm{TM} \text { ainhull }}
$$

Two adjacent hulls will cause interaction. The interaction that occurs is the interaction of waves and the interaction of the form. The effect of the interaction causes interference [10].

Interferences may be disadvantageous if interference effects increase the summation of ship resistance. Otherwise, interference can be advantageous if interference reduces the summation of ship resistance. But this still requires a lot of studies. The calculation of resistance and interference can be written by:

$$
\begin{aligned}
& \mathrm{R}_{\mathrm{T}}=3 \mathrm{R}_{\mathrm{THull}}+\Delta \mathrm{R}_{\mathrm{TV}}+\Delta \mathrm{R}_{\mathrm{TW}} \\
& \mathrm{R}_{\mathrm{T}}=3 \mathrm{R}_{\mathrm{THull}}+\mathrm{R}_{\text {interference }}
\end{aligned}
$$

Where, $\Delta \mathrm{R}_{\mathrm{TV}}$ and $\Delta \mathrm{R}_{\mathrm{TW}}$ can be summed up the interference resistance of the trimaran.

\section{Ship Seakeeping}

The definition of seakeeping is the response of ship motion when it receives from outside where it is caused by waves [2]. Seakeeping is also interpreted as measuring the ability of ships when in the waters [11] Ships must have good seakeeping qualities as sea worthiness and are considered capable of being operated effectively on various water conditions. Seakeeping calculations can be done through model testing using MOB (Manoeuvring Ocean Basin) where the parameters measured include heaving, pitching and rolling motion responses and possible slamming and deck wetness [12].

Seakeeping criteria relate to the ship's response aspect to marine conditions, such as the amplitude of roll motion, pitch, heave in certain areas on board. Seakeeping of a vessel is illustrated in Figure 3. Ship motions can be classified into 3 types of linear motion and 3 types of rotational motion as shown in Table 1.

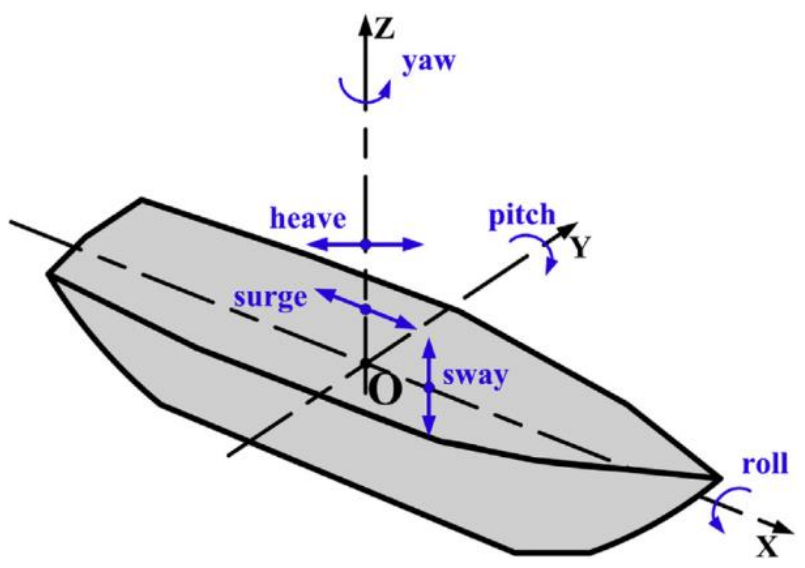

Figure 3. Six Degree of Freedom 
Table 1. Equation of Ship Motion

\begin{tabular}{|c|c|c|c|c|c|}
\hline No. & Rotation Motion & RAO & No. & Translation Motion & RAO \\
\hline 1 & Roll & $\left(\emptyset_{\mathrm{a}} / \delta_{\mathrm{a}}\right)^{2}$ & 4 & Surge & $\left(\mathrm{xa}_{\mathrm{a}} / \delta_{\mathrm{a}}\right)^{2}$ \\
\hline 2 & Pitch & $\left(\Theta_{\mathrm{a}} / \delta_{\mathrm{a}}\right)^{2}$ & 5 & Sway & $\left(\mathrm{ya} / \delta_{\mathrm{a}}\right)^{2}$ \\
\hline 3 & Yaw & $\left(\Phi_{\mathrm{a}} / \delta_{\mathrm{a}}\right)^{2}$ & 6 & Heave & $\left(\mathrm{za} / \delta_{\mathrm{a}}\right)^{2}$ \\
\hline
\end{tabular}

The main step for seakeeping calculation is to know the hydrodynamic response of the vessel according to the wave velocity and angle to the received wave load [13]. Second is getting wave spectra from the operational area to know the magnitude of the existing wave. Thus, ship behavior is obtained based on the probability of motion occurring at an approved level. Operational water conditions are described by statistical models, where the characteristics of the area are known as wave height and wave energy according to frequency and entry angle [14].

Vessel motions are calculated on the basis of wave energy spectra and Response Amplitude Operators (RAOs). During projects, ship receives forecasted wave energy spectra from sea. In addition, Trimaran shiphull measures the local frequency and direction dependent wave spectra with experiment. Regarding the RAOs, they are typically calculated using diffraction software. Wave energy spectra and motion RAOs are oth frequency and direction dependent. Given the wave spectra and the RAOs, the vessel motions can be determined. Trimaran ship hull motions are measured with ANSYS AQWA.

In order to describe the motions of a vessel, which mainly has a linear behaviour, a frequency domain analysis is performed. According to this analysis, the resulting motions of a vessel in irregular waves are calculated by adding together the vessel's response to regular harmonic waves of different amplitudes, frequencies and propagation directions. In short, given the wave spectrum and the frequency characteristics of the vessel, the motion response spectra can be determined (Figure 4).

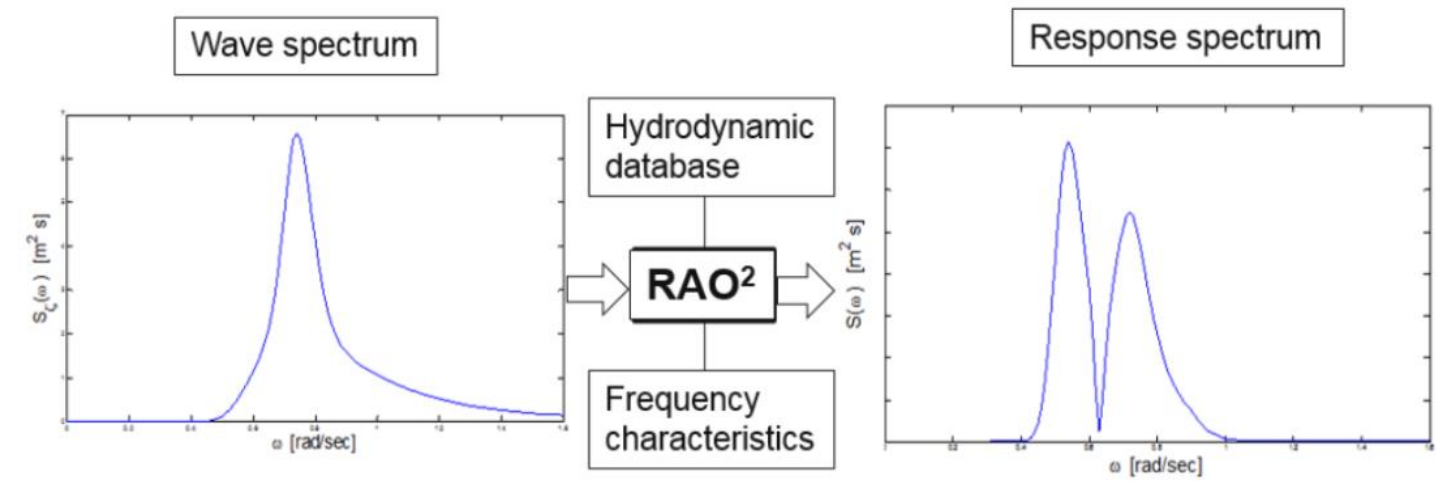

Figure 4. Calculation of Motion Response Spectra for a Ship

\section{Method}

The investigation was carried out numerically. The numerical work was carried out using commercial design software (ANSYS CFX). There are tools be used to investigate the seakeeping of trimaran, the use of CFD package-ANSYS AQWA for seakeeping analysis of trimaran.

The numerical calculation was carried out with particular body plan and settings of the model are shown in Figures 5 and Table 2. The numerical calculation was conducted at various speed (and Froude numbers) and space to length ratios or clearances (S/L) as shown in Table 3. 


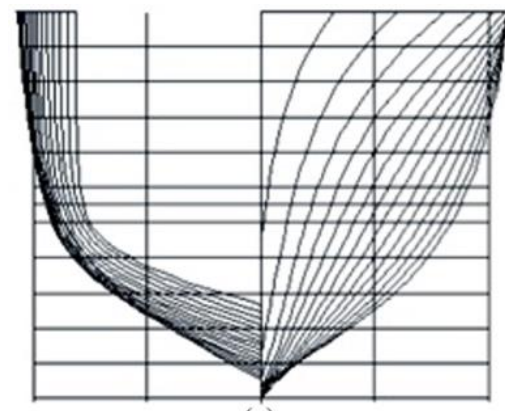

(a)

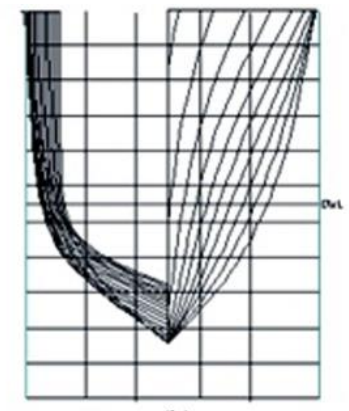

(b)

Figure 5. Body plan of model: Mainhull (a) and Sidehull (b)

Table 2. Principle Particulars of Trimaran Vessel And Model

\begin{tabular}{|l|l|l|l|}
\hline $\begin{array}{c}\text { Particallary } \\
\text { Dimension }\end{array}$ & Unit & Trimaran vessel & CFD Model \\
\hline LOA & $\mathrm{m}$ & 74.14 & 1.2525 \\
\hline LPP & $\mathrm{m}$ & 72.09 & 1.2178 \\
\hline B Mainhull & $\mathrm{m}$ & 9.91 & 0.1675 \\
\hline B Sidehull & $\mathrm{m}$ & 5.71 & 0.0965 \\
\hline $\mathrm{B}(\mathrm{S} / \mathrm{L}=0.2)$ & $\mathrm{m}$ & 34.55 & 0.5836 \\
\hline $\mathrm{B}(\mathrm{S} / \mathrm{L}=0.3)$ & $\mathrm{m}$ & 48.98 & 0.8274 \\
\hline $\mathrm{B}(\mathrm{S} / \mathrm{L}=0.4)$ & $\mathrm{m}$ & 63.38 & 1.0707 \\
\hline $\mathrm{B}(\mathrm{S} / \mathrm{L}=0.5)$ & $\mathrm{m}$ & 77.94 & 1.3166 \\
\hline $\mathrm{H}$ & $\mathrm{m}$ & 7.16 & 0.1210 \\
\hline $\mathrm{T}$ & $\mathrm{m}$ & 3.951 & 0.0667 \\
\hline WSA & $\mathrm{m}$ & 1367.93 & 0.3904 \\
\hline Displacement & ton & 1440.00 & 0.006942 \\
\hline
\end{tabular}

Table 3. Configuration and Various Speed of Test

\begin{tabular}{|c|c|c|}
\hline Froude Numbers $(\mathbf{F r})$ & Type of ship & Clearance $(\mathbf{S} / \mathbf{L})$ \\
\hline $0.15 ; 0.17 ; 0.19 ; 0.21 ; 0.23 ; 0.25 ; 0.27$ & Trimaran & $0.2 ; 0.3 ; 0.4 ; 0.5$ \\
\hline
\end{tabular}

\section{CFD Analysis}

\subsection{Resistance}

CFD analysis was carried out in order to figure out the flow movement phenomenon thus contributes to the decrease or increase of total resistance. Several work on the resistance investigation have been done such as reported by $[15,16,17]$.

The boundary conditions are set as follows as suggested by $[15,18]$. The inlet boundary is defined as a uniform flow with velocity equals the ship velocity. It is located at $1.5 \mathrm{~L}$ upstream from the ship. Then, at a location of $4 \mathrm{~L}$ downstream from the ship is outlet boundary, it is given as that the pressure distribution after ship modelling. Furthermore, the distance with two sides of boundary is made $1.5 \mathrm{~L}$ and distance with top and bottom boundaries is set $2.5 \mathrm{~L}$. The Ship modelling is defined no-slip at the hull surface. Wall is defined free-slip. Details of the description can be seen in Figure 5. The investigation was conducted with free surface effect.

The choice of turbulence models is found to be very crucial in the simulation of wake fields. SST (Shear Stress Transport) turbulence model is used to solve current study. This turbulence model is 
developed by $[19,20]$ and the SST model has been used and validated by several researchers including [21] and [22] with successful results. The mathematical model flow to solved this case is using RANS (Reynolds Averaged Navier-Stokes) solver implemented in ANSYS CFX.

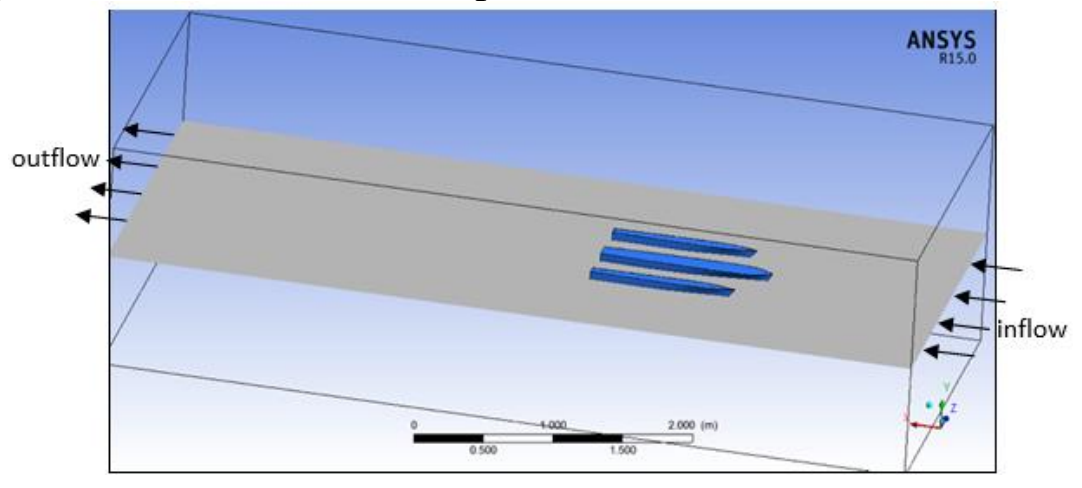

Figure 5. Setting of Model and Boundary Conditions in CFD Domain

\subsection{Seakeeping}

The CFD-ANSYS AQWA program consists of five stages: Geometry, Model, Set-up, Solution and Result. Geometry is used in the stage of making a trimaran ship model, then making meshing is done in the Model stage. Furthermore, the determination of the test conditions in the Set-up and Solution set is used for the process of problem solving process. Set up model and wave are shown in Figure 6 and Table 4.

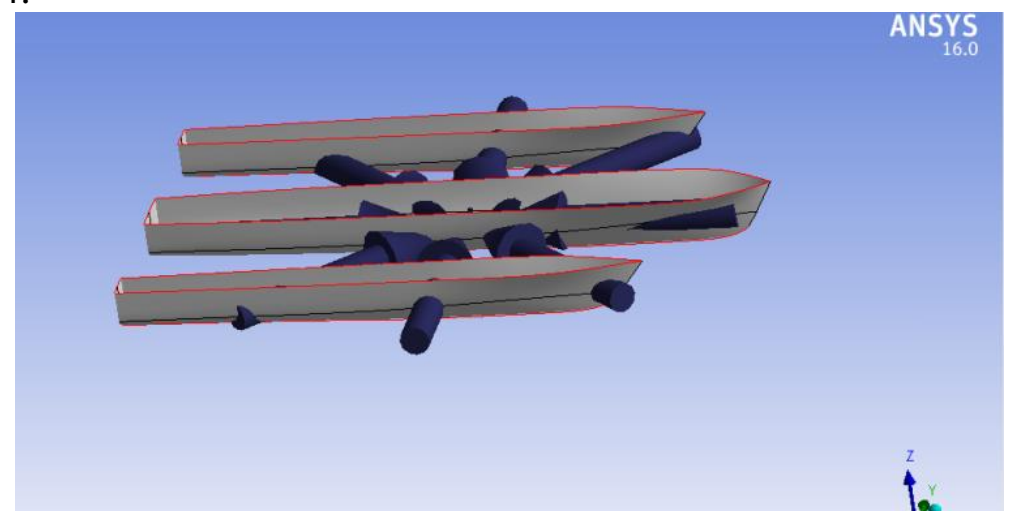

Figure 6. Set-up Model

The CFD analysis to be performed on trimaran ship modeling is the RAO that is due to external forces in the form of trimaran ship waves and visualization of results.

Table 4. Set Up of Wave

\begin{tabular}{|r|l|}
\hline Object Name & Wave Directions \\
\hline State & Fully Defined \\
\hline Required Wave Input & \\
\hline Wave Angle Range & $-180^{\circ}$ to $180^{\circ}$ \\
\hline Interval & $45^{\circ}$ \\
\hline
\end{tabular}




\section{Result and Discussions}

The apparent correlation between resistance and seakeeping is the larger S/L change hence the small resistance occurs due to the absence of interference.

Table 5 and Figure 7 show the correlation coefficient of total resistance and RMS heave where at $\mathrm{S} / \mathrm{L}=0,5$ shows the highest RMS heave value that is equal to 0.34 degree at angle 0 degree whereas $\mathrm{CT}$ at the condition is the smallest. This shows that in the condition of resistance without interference (the least resistance) at $\mathrm{S} / \mathrm{L}=0.5$ has a large heave value. This is due to the absence of interference to reduce the size of the heave.

Table 5. Correlation between $\mathrm{Ct}$ and RMS Heave

\begin{tabular}{|c|c|c|c|c|c|}
\hline \multicolumn{2}{|c|}{$\mathrm{S} / \mathrm{L}$} & 0.20 & 0.30 & 0.40 & 0.50 \\
\hline \multicolumn{2}{|c|}{$\mathrm{CT}\left(\mathrm{x} 10^{-3}\right)$} & 5.97 & 5.45 & 5.27 & 5.14 \\
\hline \multirow{5}{*}{ 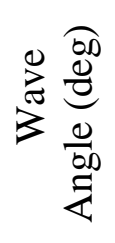 } & 0 & 0.21 & 0.25 & 0.28 & 0.34 \\
\hline & 45 & 0.23 & 0.25 & 0.26 & 0.30 \\
\hline & 90 & 0.17 & 0.29 & 0.18 & 0.16 \\
\hline & 135 & 0.26 & 0.27 & 0.25 & 0.24 \\
\hline & 180 & 0.30 & 0.31 & 0.30 & 0.30 \\
\hline
\end{tabular}

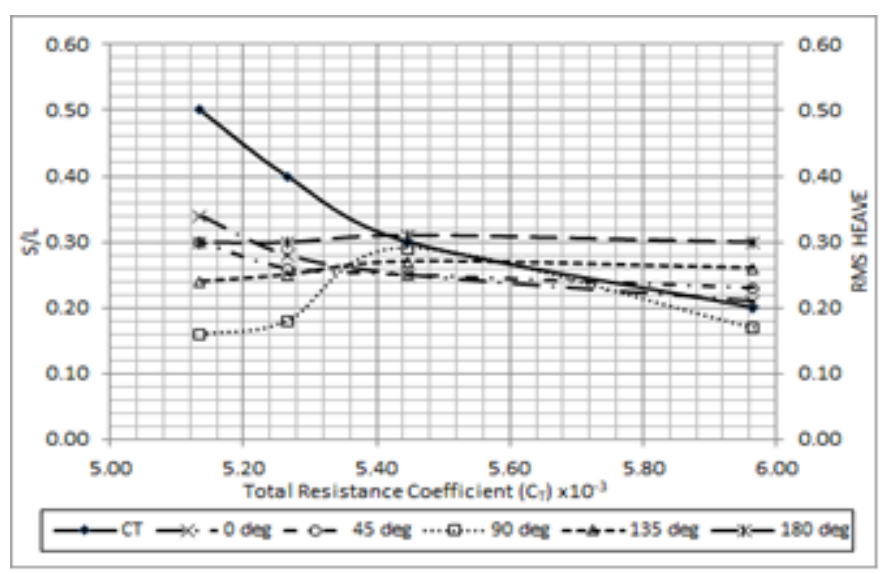

Figure 7. Correlation between CT and RMS Heave

Furthermore, in Table 4, there is a correlation coefficient of total resistance and RMS Pitch where at $\mathrm{S} / \mathrm{L}=0,5$ shows the highest RMS heave value that is equal to 0,54 degree at angle 0 degree whereas CT has the smallest value. This indicates that in the condition of resistance without interference at $\mathrm{S} / \mathrm{L}=0.5$ has a considerable pitch value. This indicates the absence of interference then the greater the pitch value. Positive interference effects occur at $\mathrm{S} / \mathrm{L}=0.2$ which has an $\mathrm{RMS}$ of 0.12 . Correlation Resistance and RMS Pitch on variations of trimaran vessels are shown in Figure 8.

Table 4. Correlation between $\mathrm{C}_{\mathrm{T}}$ and RMS Pitch

\begin{tabular}{|c|c|c|c|c|c|}
\hline \multicolumn{2}{|c|}{$\mathrm{S} / \mathrm{L}$} & 0.20 & 0.0 & 0.40 & 0.50 \\
\hline \multicolumn{2}{|c|}{$\mathrm{C}_{\mathrm{T}}\left(\mathrm{x} 10^{-3}\right)$} & 5.97 & 5.45 & 5.27 & 5.14 \\
\hline \multirow{5}{*}{ 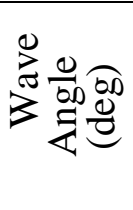 } & 0 & 0.51 & 0.52 & 0.52 & 0.54 \\
\hline & 45 & 0.44 & 0.43 & 0.43 & 0.42 \\
\hline & 90 & 0.24 & 0.18 & 0.17 & 0.30 \\
\hline & 135 & 0.34 & 0.33 & 0.32 & 0.36 \\
\hline & 180 & 0.39 & 0.36 & 0.36 & 0.39 \\
\hline
\end{tabular}




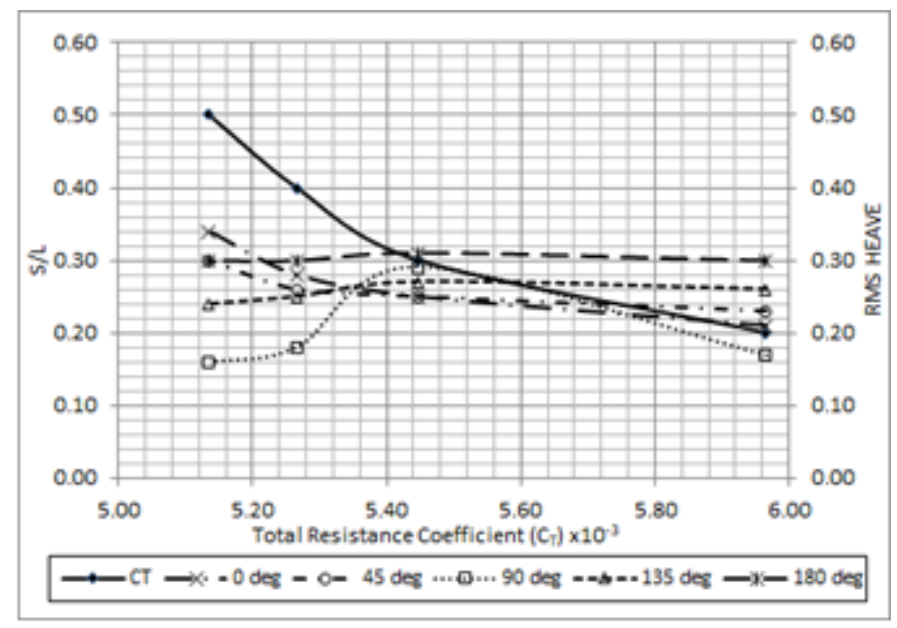

Figure 8. Correlation between CT and RMS Pitch

Correlation Resitance and RMS Roll shown in Table 5 shows where at $\mathrm{S} / \mathrm{L}=0.2$ shows the largest RMS Roll value of 3.68 degrees at the angle 0 degrees whereas $\mathrm{CT}$ at the condition is quite large. This suggests that in conditions of resistance with large interference at $\mathrm{S} / \mathrm{L}=0.2$ has no significant effect on Roll motion. Thus, it can be concluded while the interference is not influenced significantly due to trimaran ship roll motion. Correlation between Resistance and RMS Roll on trimaran ship variations are shown in Figure 9.

Table 5. Correlation between $\mathrm{C}_{\mathrm{T}}$ and RMS Roll

\begin{tabular}{|c|c|c|c|c|c|}
\hline \multicolumn{2}{|c|}{$\mathrm{S} / \mathrm{L}$} & 0.20 & 0.30 & 0.40 & 0.50 \\
\hline \multicolumn{2}{|c|}{$\mathrm{C}_{\mathrm{T}}\left(\mathrm{x} 10^{-3}\right)$} & 5.97 & 5.45 & 5.27 & 5.14 \\
\hline \multirow{3}{*}{$\approx 0$} & 0 & 0.00 & 0.00 & 0.00 & 0.00 \\
\cline { 2 - 6 } & 45 & 1.90 & 1.16 & 1.00 & 0.85 \\
\cline { 2 - 6 } & 90 & 2.68 & 2.51 & 2.00 & 1.98 \\
\cline { 2 - 6 } & 135 & 1.71 & 1.31 & 1.19 & 1.30 \\
\cline { 2 - 6 } & 180 & 0.00 & 0.00 & 0.00 & 0.00 \\
\hline
\end{tabular}

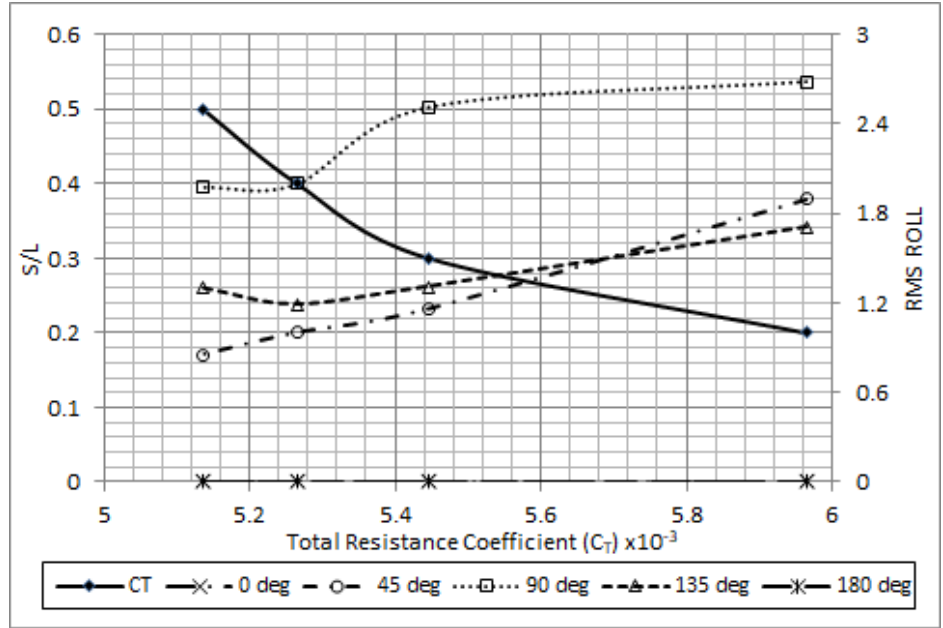

Figure 9. Correlation between $\mathrm{C}_{\mathrm{T}}$ and RMS Roll 


\section{Conclusion}

The apparent correlation between resistance and seakeeping is the change in $\mathrm{S} / \mathrm{L}$ the greater the resistance that occur is the smaller because there is no interferenation. otherwise to $\mathrm{S} / \mathrm{L}=0.2$ the resistance that occur are the greatest of these because of the interferences between hulls.

From this research that the ship interference can reduce the ship's RMS heave and pitch at S/L $=0.2$, while the interference is not influced significantly due to trimaran ship roll motion. The RMS in the next stage can affect the pattern of ship motion.

From each variation of $\mathrm{S} / \mathrm{L}$ on the trimaran vessel then performed numerical calculation can be done optimization. At $\mathrm{S} / \mathrm{L}=0.4$ indicates optimal trimaran variation to sail at service speed condition $(\mathrm{Fr}=0.21)$ with wave height 1 meter (seastate 4$)$. The acquisition of the price is based on the hydrodynamic aspect. So it is necessary to conduct a more in-depth study related to the structure and passenger comfort test. The results of these initial conclusions can be used as science databases and can be done for further research with different aspects of the review.

\section{Acknowledgements}

The authors gratefully thanked to the University of Pattimura Ambon and the University of Hang Tuah Surabaya which funded and supported this research.

\section{References}

[1] Meteorology Climatology and Geophysics Agency of Maluku, 2014

[2] Rameswar Bhattacharyya, "Dynamics of Marine Vehicles",. John Wiley and Sons. USA. 1998

[3] Directorate General of Sea Transport, 2014

[4] W. Froude, "Experiments on the surface-friction experienced by a plane moving through water", British Association for the Advancement of Science, 138-146. 1872

[5] A.F Molland, "A Guide to Ship Design, Construction and Operation", The Maritime Engineering Reference Book, Butterworth- Heinemann, Elsevier. 2008

[6] G. Hughes. "Friction and Form Resistance in Turbulent Flow and a Proposed Formulation for Use in Model and Ship Correlation”, Trans INA, Vol. 96.1954

[7] ITTC-1957. "Proceedings of the 8th ITTC", Madrid, Spain, Canal de Experiencisas Hidrodinamicas, El Pardo, Madrid.

[8] ITTC-1978, “ Report of Performance Committee,” 15th ITTC, Hague.

[9] Insel, M dan A F Molland, "An Investigation into the Resistance Components of High Speed Displacement Catamarans”, Trans RINA Vol. 134,1992

[10] V. Dubrovsky and A. Lyakhovitsky, Multi-hull ShipsBackbone Publishing Company, 2001.

[11] St. Denis, "Some comments on the ISSC Variance Spectrum of the Seaway," contribution to discussion of report of Committee 1.1, 6th ISSC, Cambridge, Mass. 1976

[12] Fryer,D. K.,Johnson, M. Hwakes, "Testing the Seakeeping Performance of Ship Models in Natural Seas", International Shipbuilding Progress, Vol.41, pp.5-23.1994

[13] S. Esteban, J. M. Giron-Sierra, B. de Andres-Toro, and J. M. de la Cruz, "Development of a control-oriented model of the vertical motions of a fast ferry, "Journal of Ship Research, vol. 48, no. 3, pp. 218-230, September 2004.

[14] Richard B Luhulima, I.K.A.P Utama, Aries Sulisetyono, "An Investigation Into The Correlation Between Resistance And Seakeeping Characteristics Of A Displacement Trimaran”, The $3^{\text {rd }}$ International Conference of Ocean, Mechanical and Aerospace, Scientists and Engineers (OMAse), 7-8 November 2016, Terengganu, Malaysia.

[15] I.K.A.P Utama and A.F Molland, "Experimental and Numerical Investigations into Catamaran Viscous Resistance”, FAST'2001, Southampton, UK.

[16] Siqueira, C. L. R., Spogis, N., Damian, R., Reis, M., “Overview of CFD Modeling for Ship Hull Interactions with Waves and Propellers", $3^{\text {rd }}$ International Workshop on applied Offshore Hydrodynamics, Brazil, 17-19 October, 2007

[17] A. Jamaludin, Desertasi, Kajian Eksperimen Dan Numerik Interferensi Hambatan Viskos Dan Gelombang Pada Lambung Kapal Katamaran ITS,2012. 
[18] Y Ahmed and C.G. Soares, "Simulation of Free Surface Flow Around a VLCC Hull Using Viscous and Potential Flow Methods”, Ocean Engineering 36, p.691-696, (2009)

[19] F.R. Menter, "Zonal Two Equation k- $\omega$ Turbulence Models for Flows”, AIAA Paper 93 - 2906. 1994

[20] F.R. Menter, "Two-Equation Eddy-Viscousity Turbulence Models forEngineering Applications", AIAA Journal, Vol. 32, pp. 289-289, 1993

[21] J.E., Bardina, P.G., Huang, and T.J. Coakley, (1997), “Turbulence Modelling,Validation, Testing and Development”, NASA Technical Memorandum110446, 1997

[22] H. Versteeg and W. Malalasekera, "An Introduction to Computational Fluid Dynamics: The Finite Volume Method Pearson Education (US), 2007 